\title{
Jesuit Strategic Scepticism toward Religious Self-Consciousness and Commonalities: Chinese Muslims, Jews, and Christians in the Eyes of Matteo Ricci (1552-1610) and His "Translator" Nicolas Trigault (1557-1628)
}

In 1616, a book about an expedition to China was published by the Walloon Jesuit Nicolas Trigault (Trigau(l)tius in Latin), whose Chinese name was Jin Nígé, 金尼 閣. ${ }^{1}$ This book was a report of the Chinese "expedition," to use his own title, made by the famous Jesuit Matteo Ricci. ${ }^{2}$ Ricci's "expedition” is relatively important because 1) it testifies to the Muslim and Christian presence in China in the early modern period and that of the Jews in Kaifeng in the province of Henan in the sixteenth and seventeenth centuries and 2) it gives us a portrait of three "European" or occidental religions (which are referred to as "sects") and their development in the eyes of an intellectual Christian who was a missionary traveller. If the reports could qualify as more or less historically plausible, they could help us to understand religious commonalities between social groups in their past and present and their consciousness of belonging to a religion. Yet Ricci and Trigault pursued different goals, revealed by their different styles and strategies, which are the object of the present paper.

The interpretative categories used here will be narratively illustrated later in the context in which they are adopted. Yet it should first be noted that sceptical strategies are dialectical tools, mostly tacitly implied, which aim to demolish or at least weaken an argumentation, a belief, or the claimed verity of a fact. Ancient scep-

\footnotetext{
1 I would like to thank my friend and colleague Michael Friedrich, professor of Sinology at Universität Hamburg, for inviting me to the Hamburg Shanghai Forum (Universität Hamburg and Fudan University) from April 10 to 13, 2019. His invitation and his accurate and fruitful advice were the initial motivation for my interest in the story of the Jesuit mission in China in the early modern period. My reading of the text is exclusively devoted to its literary strategy and is concerned with little, if any, historical research on the circumstances of the origins and propagation of both writings. I have not addressed the problem of their plausibility, nor will I deal with Chinese primary sources to contrast or confirm the observations and claims of both Jesuits. My approach is from the perhaps narrower angle of the history of ideas and strategies. I refer the reader to the vast literature on the topic. For the history of the Jesuits, see now the recent volume by Markus Friedrich, Die Jesuiten. Aufstieg, Niedergang, Neubeginn (Munich: Piper, 2016) and the literature mentioned there.

2 Nicholas Trigault, De Christiana expeditione apud Sinas suscepta ab Societate Jesu. Ex P. Matthaei Riccij eiusdem societatis commentarijs, libri V: Ad S.D.N. Paulum V. In quibus sinensis regni mores, leges, atque instituta, \& novae illius Ecclesiae difficillima primordia accurate \& summa fide describuntur (Leiden, 1616). See further details below.
} 
tics did not aim to reconstruct the theory, idea, arguments, or philosophy they were defeating. In the following analysis, I will introduce the concept of strategic scepticism as a tactic for disavowing authorities, facts, ideas, or groups with the intention of suggesting alternative authorities and interpretations as premises for new dogmatisms. As is well known, the philosophical term "sceptic" philologically means "researcher," without the methodological implication of the double aspect of the Scholastic pars destruens as a premise of the pars construens. ${ }^{3}$ In the present case, I suggest understanding strategic scepticism in the sense of the current strategic procedure used in spreading "fake news"; namely, insinuating doubts and uncertainty, but supporting other concurrent systems of power. ${ }^{4}$

In what follows, I will present and discuss the report on the three religious groups in the eleventh paragraph of the first chapter of Trigault's book and the corresponding parts of Ricci's original Italian, mostly scattered throughout his diary. I will also raise questions about the internal logic, additions, points of contrast, and possible plausibility of both the original Italian version and Trigault's Latin translation.

\section{Ricci's Text and Trigault's Translation}

To begin with, I must answer the implicit question of why we should consider a translation together with the original, or Vorlage. The answer is simple: the Latin translation of the book was highly influential, as the history of its printings and translations testifies: it was printed four times (in 1615, 1616, 1617, and 1619); there were three French versions (published in 1616, 1617, and 1618); it was published in German (1617), Spanish (1621), and Italian (1621); excerpts from it appeared in English in Hakluytus Posthumus or Purchas his Pilgrimes, contayning a History of the World in Sea Voyages and Lande Travells, by Englishmen and others (4 vols., 1625); ${ }^{5}$ and finally, a complete English version was published in 1953. In contrast, the first Italian edition of Matteo Ricci's work was published in Macerata, Ricci's birthplace, as late as $1911 .{ }^{6}$ The world of scholarship had to wait three more decades for his com-

3 See Giuseppe Veltri, Alienated Wisdom: Enquiry into Jewish Philosophy and Scepticism (Berlin and Boston: De Gruyter, 2018), 146-56.

4 See below.

5 Full title: Hakluytus Posthumus in fiue bookes. The first, contayning the voyages and peregrinations made by ancient kings, patriarkes, apostles, philosophers, and others, to and thorow the remoter parts of the knowne world: enquiries also of languages and religions, especially of the moderne diuersified professions of Christianitie. The second, a description of all the circum-nauigations of the globe. The third, nauigations and voyages of English-men, alongst the coasts of Africa [...] The fourth, English voyages beyond the East Indies, to the ilands of Iapan, China, Cauchinchina, the Philippinæ with others [...] The fifth, nauigations, voyages, traffiques, discoueries, of the English nation in the easterne parts of the world [...] The first part Hakluytus posthumus or Purchas his pilgrims (London, 1625).

6 Opere storiche del padre Matteo Ricci S.I, ed. Pietro Tacchi (Macerata: F. Giorgetti, 1911-13). 
plete works: in 1942, the first volume of Fonti Ricciane, edited by Pasquale d'Elia, appeared, and the second and third volumes were published in $1949 .^{7}$

In the very first lines of the book, Trigault writes: ${ }^{8}$

Ricci's commentaries were intended for Europe, and for fear that the record of the labor of so great a man might be lost amid the perils of such a long journey, and the dangers of overland travel on pack animals, it was decided to translate them into Portuguese, and to retain a copy of what he had written in Italian. ${ }^{9}$

Despite Trigault's statement about the danger of the text being lost, the reason for publishing the Latin translation before the Italian edition is not clear. We must remember that the Christian Portuguese presence in China (primarily in Macau) played a major role in this period, and we should also remember that Ricci, together with Michele Ruggieri, composed the first Dicionário Português-Chinês (Pu-Han cidian) in $1594,{ }^{10}$ although it remained unpublished until 2001. From the point of view of market economy, we can guess that one important reason was that the translation into Portuguese had the potential to conquer the market. However, I do not think so. To explain his translation, Trigault made recourse to his personal commitment to his mission in China; he claimed that he himself was the sole authority regarding the transfer of knowledge between China and the occident. He openly writes:

The status of the Christian Mission to China at that time demanded that a Procurator be sent to Europe to promote the mission interests, and being selected for this office, my first thought was to read the manuscript of father Matthew Ricci's commentaries and translate them into Latin. My reasons for thinking so were, first, because I realized that this task could not be done by anyone who was not well acquainted with the affairs of the Mission, or with the various parts of the country that are mentioned, and secondly, as we have already said, because it was necessary to fill in various parts that were left unfinished, also to add certain items and to amplify others, which our good father, in his modesty, had either omitted entirely, or only touched upon in passing. And so, although the sea voyage was long, the weather clear, and the sea calm, the work of transla-

7 Fonti Ricciane: documenti originali concernenti Matteo Ricci e la storia delle prime relazioni tra l'Europa e la Cina (1579-1615), ed. Pasquale M. d'Elia, 3 vols (Rome: La Libreria dello Stato, 1942-49). There are of course new translations of the original into modern languages as well as into Chinese, which I will not take into consideration for obvious reasons.

8 Here, I am using the English translation offered in Matthew Ricci, China in the Sixteenth Century: The Journals of Matthew Ricci, 1583-1610, trans. Louis J. Gallagher (New York: Random House, 1953), downloaded from http://www.questia.com/read/11620863/china-in-the-sixteenth-century-the-journals-ofmatthew.

9 Ricci, China in the Sixteenth Century, xiii. All emphases are mine.

10 Michele Ruggieri and Matteo Ricci, Dicionário Português-Chinês: 葡漢辭典 (Pu-Han cidian): Portuguese-Chinese Dictionary, ed. John W. Witek (Lisbon and San Francisco: Biblioteca Nacional Portugal, Instituto Português do Oriente and Ricci Institute for Chinese-Western Cultural History, University of San Francisco, 2001). It is beyond my intent and capacity to answer the question of whether Ricci was a co-author of this dictionary or only its front man. 
tion was no small undertaking, and I realized that I had endeavored to accomplish something that demanded more leisure and more quiet than was customary among a crew of noisy sailors. ${ }^{11}$

We will return to Trigault's "real" intention at the end of this essay. An intention that is, in my opinion, secondary-or perhaps entirely absent-is to acquaint his audience with the richness and multifariousness of the Chinese world. One should also exclude the possibility that Trigault intended to offer an "ethnography" of Chinese customs and beliefs, similar to modern researchers' claims concerning Christian reports about the Jews in the seventeenth century. ${ }^{12}$ Yet, ethnography was not a seventeenthcentury science; the central aspect of collecting customs and beliefs was not a concern with expressions of human diversity as represented by ethnic divisions and cultural and social cults and beliefs, but almost always a polemic and apologetic literature. The report about Chinese philosophy and customs shows some interesting parallels in their polemical and apologetic aspects to the Christian European interest in the so-called ceremonialia of the Jews and Turks. We will analyse them in the conclusion. Here, it is enough to note that it must have been evident to the reader that the intention of this report is exclusively concentrated in the phrases "to promote the mission interests" and "fill in various parts [of Ricci's works] that were left unfinished."13 It is clear that Trigault wanted to establish a permanent Jesuit mission to disseminate Christian Roman Catholic tradition in China, given his claim that he is presenting an accurate report on the mission. Trigault goes beyond Ricci's account: he claims that his own additions are also based on evidence from eyewitnesses:

As for myself, I can assure you that what I have added, I have seen with my own eyes, or have obtained it from the true report of other fathers, who either witnessed it themselves, or approved of it for the annals of the Mission. I have not only visited China but have traversed six of its principal provinces, seen all the Mission Centers and, as I believe, garnered a thorough knowledge of the affairs of the Mission in general. We thought it best to inform you of all this, even at length, lest you be led into doubt by the contrary opinions appearing in the various writings thus far edited concerning the Kingdom of China. ${ }^{14}$

The historical accuracy of the report-namely, how precise it is in its historical details or, on the contrary, how in some ways it was ingeniously fabricated as though by an inventive storyteller-remains unclear. It is not my task to answer this question, but rather to present some thoughts and considerations that occurred to me following my reading of both versions, leaving to other scholars, who are assuredly much more acquainted with Chinese history in the early modern period, the heavy

11 Ricci, China in the Sixteenth Century, xiii.

12 See, e.g., Yaacov Deutsch, Judaism in Christian Eyes: Ethnographic Descriptions of Jews and Judaism in Early Modern Europe (Oxford: Oxford University Press, 2012) and my criticism in Veltri, Alienated Wisdom, 69-89.

13 Both texts are quoted from Ricci, China in the Sixteenth Century.

14 Ricci, xiv. 
task of looking into both books and the possible sources and materials used by each author.

\section{The Report on Chinese Religion, Muslims, Jews, and Christians}

At the end of the first chapter, Trigault reports on Ricci's meetings with Muslims, Jews, and Christians in China ("11. Signs of the Doctrines of the Saracens, the Jews, and of Christianity among the Chinese"). In the Fonti Ricciane, the corresponding text is very short. Ricci begins with a preface on the religions which he called sects "which are around the religion," meaning the ancient Chinese religion. His admiration cannot be underestimated, as he compares the ancient Chinese religion and philosophy with those of the Greco-Roman world by emphasising the superiority of the Chinese. He believes the ancient Chinese concept of divinity to be superior because it is not blemished by sexual obscenities like the Greco-Roman Olympus. Chinese adepts, on the contrary, followed reason. As he was of the school of a typical Scholastic interpretation of religious consciousness, Ricci expressed his hope that the ancient Chinese believers had reached salvation through natural law. Peter Duigman asserts that "the Jesuits [...] had a more flexible system of moral philosophy and a broader concept of natural law than did other Catholic missionaries." ${ }^{15}$ I am somewhat perplexed by this general statement-a Jesuit commitment of sorts to relativism à la Montaigne-when confronted with the evident goal of Ricci's note about ancient philosophy and religion. He states that the antique Chinese (and only they) could reach this natural salvation through their good works, "the love of their homeland, of the public good, and the benefit of the people."16

Ricci has high esteem for ancient Chinese philosophy, which in his opinion cannot be considered to be inferior to European philosophy (senza niente cedere ai più famosi dei nostri philosophi antichi). Nevertheless, the conclusion of the paragraph is clear: the corrupt nature of human beings without divine grace can only produce idolatry and atheism. The door to true Christianity is hence open. That is not relativism, but a sceptical strategy for indirectly attacking Greek philosophy by creating an opponent, i.e., Chinese philosophy, that demolishes the uniqueness of Greek reason on behalf of a philosophy that is even better due to its superior morality. The pars construens is of course Christianity, the only religion in which faith, morals, and reason are perfectly suited to the goal of salvation.

15 Peter Duigman, "Early Jesuit Missionaries: A Suggestion for Further Study,” American Anthropologist 60 (1958): 729.

16 "Le buone opere che fecero quei primi Cinesi per amore della patria, del bene pubblico et utilità del popolo" (Nr. 170). 
As for Trigault, he intriguingly refers to salvation according to the Scholastic doctrine of conscientia:

One can confidently hope that in the mercy of God, many of the ancient Chinese found salvation in the natural law, assisted as they must have been by that special help which, as the theologians teach, is denied to no one who does what he can toward salvation, according to the light of his conscience. That they endeavored to do this is readily determined from their history of more than four thousand years, which really is a record of good deeds done on behalf of their country and for the common good. ${ }^{17}$

This self-consciousness is an important element of Thomas Aquinas's theology of other religions, which states that a person can be saved by the fact of belonging to the true religion, a motif which goes back to the Islamic philosopher Abu Ḥāmid Muhammad ibn Muḥammad al-Ghazālì (1058-1111). There is no space to go into this concept in more detail here, which at first glance attempts to be a solution to the problem of the diversity of monotheisms and revealed religions. I said "at first glance," because the hidden reason for introducing it is not relativism, but the strategic way of introducing the Christian truth: the non-Christian can only reach salvation via natural law and "according to the light of his conscience." How can the conscience be illuminated if not by the light of the Gospel? ${ }^{18}$

Trigault emphatically mentions the ancient Chinese religion and philosophy, although his tone is less enthusiastic than Ricci's. In this context, he reports on the three Chinese "sects." Listing the Chinese cults, i.e. the practical observances, he reduces them to "the Literati, the Sciequia, and the Laucu,"19 whose common element is the Chinese script used by the Japanese, Koreans, and Formosans who belong to these three sects. Here, for the first time, he speaks of the "traces of Saracen, Judaic, and Christian worship evident in China." ${ }^{20}$ At first glance, it is not evident why Ricci and Trigault list these three religions in a non-chronological order.

17 Ricci, China in the Sixteenth Century, 93.

18 On the principle of conscientia, see Giuseppe Veltri, "The Principle of Coscientia: The Averroist Joshua ha-Lorqi" (in preparation).

19 That is, the Confucians, Buddhists (from Shijia), and Daoists (from Laozi). I am grateful to Michael Friedrich for this information.

20 Ricci, China in the Sixteenth Century, 94: "In this chapter, we shall treat only of the triple cult of the Chinese as distinguished from all other pagan sects. [...] Chinese books enumerate only three cults or systems of religious observance for the whole world and this people knows of no others. These are, the Literati, the Sciequia, and the Laucu. All Chinese and all people of the surrounding nations who make use of Chinese writing - the Japanese, the Koreans, the Leuquici or Formosans, and the Cochin Chinese - belong to one or other of these three sects.” 


\section{Muslims}

The mention of the ancient Chinese religion is also the context in which Ricci introduces the three groups or sects present in China. The Muslims are presented as making a decisive contribution to the decadence initiated by the Chinese, coming from Persia and pouring into China in increasing numbers throughout the generations, leading to the formation of many thousands of families (e si moltiplicarono tanto per generatione ne' suo figlioli e nipoti, che già hanno impita la Cina con molte migliaia di famiglie). ${ }^{21}$ Ricci adds that they are not missionaries and are obedient to Chinese law. They are ignorant and therefore irrelevant for the Chinese authorities, who allowed them to study and become graduates and magistrates of the Empire, and accordingly, they abandoned their religion, with exception of eating pork, to which they were not accustomed (non gli restando altrio di essa che il non mangiare care di porco per non essere avezzi ad essa). ${ }^{22}$

The corresponding paragraph in Trigault is also devoted to Muslims. For the most part, he translates Ricci's main ideas with some more particular narrative elements on the introduction of Islam into China: their character as outsiders on the one side, and their full integration into society on the other. ${ }^{23}$ The reader understands that integration is tantamount to conversion, although the commonality between converted and non-converted Muslims is the custom of avoiding the consumption of pork. Are they outsiders or insiders? This is a paradox I cannot understand.

\section{Jews}

Ricci states that very few Jewish families have remained in China and that they are only present in Henan (Kaifeng) and the province of Hanceufu. ${ }^{24}$ These families possess a parchment scroll, which they consider very precious, bearing the Pentateuch of Moses written in Hebrew letters without vocalization. They still practise the rite of circumcision and do not eat pork or meat with nerves, according to their old tradition.

21 Nr. 171.

22 Nr. 171.

23 It is not my intention here to give a historical analysis of what Ricci and Trigault wrote, but only to follow their argumentation.

24 On the history of Chinese Jews, see Hyman Kublin, Studies of the Chinese Jews: Selected Articles from Journals East and West (New York: Paragon, 1971), with contributions from Laurence Kramer, Donald Leslie, and Adolf Neubauer, among others; Anson H. Laytner and Jordan Paper, eds., The Chinese Jews of Kaifeng: A Millennium of Adaptation and Endurance (Lanham, MD: Lexington Books, 2017). 
Trigault's report substantially differs from Ricci's in the context of the three religions or sects: here, he introduces narratives of the Jews' first introduction into China by retelling Ricci's meeting with a Jew of Kaifeng:

\begin{abstract}
Some few years after our Society had taken a fixed residence in Pekin, a man who was Jewish by race and by profession, learning of the reputation of Father Ricci, decided to pay him a visit. He had read about Ricci and his companions in a book about the Europeans, written by a Chinese scholar. The man's name was Ngai and he was born in Chaifamfu, the metropolitan city of the Province of Honan. At that time he was on his way to Pekin to take the examinations for the doctorate. He had already attained to the order of the licentiate. Being a Jew and having read in the book mentioned that our Fathers were not Saracens and that they believed in only one God of heaven and earth, he concluded that we must be believers in, and followers of, the Mosaic Law. On entering our home he seemed to be quite excited over the fact, as he expressed it, that he professed the same faith that we did. His whole external appearance, nose, eyes, and all his facial lineaments, were anything but Chinese. Father Ricci took him into the church and showed him a picture above the high altar, a painting of the Blessed Virgin and the child Jesus, with John the Precursor, praying on his knees before them. Being a Jew and believing that we were of the same religious belief, he thought the picture represented Rebecca and her two children, Jacob and Esau, and so made a humble curtsy before it. He could not refrain, as he remarked, from doing honor to the parents of his race, though it was not his custom to venerate images. This happened on the Feast of St. John The Baptist. ${ }^{25}$
\end{abstract}

It is not important to ascertain whether or not this story is true. The goal is clear: to underline the Jew's ignorance. An important part of the story is that the Jew Ngai cannot read Hebrew: ${ }^{26}$

When he brought the visitor back to the house and began to question him as to his identity, it gradually dawned upon him that he was talking with a believer in the ancient Jewish law. The man admitted that he was an Israelite, but he knew of no such word as Jew. It would seem from this that the dispersion of the ten tribes penetrated to the extreme confines of the East. Later on Ngai saw a royal edition of the Bible, printed by Plantin, and though he recognized the Hebrew characters he could not read the book. ${ }^{27}$

It is obviously possible that the Jew of Kaifeng did not understand Hebrew, but not certain. In 1895, Adolf Neubauer published an article on the Jews of China ${ }^{28}$ which predominantly focused on Hebrew documents brought from China. These manuscripts are, in his opinion, very important because of their Persian influence. Neubauer was also of the opinion that Kaifeng's Jews had not mastered Hebrew. His argument relies upon a nineteenth-century report and also, of course, upon Ricci's report. I am not entirely convinced, because Ricci had only met one Jew; namely, Ngai, who

25 Ricci, China in the Sixteenth Century, 107-8.

26 On Ricci and Trigault's lack of accuracy, see Paul Pelliot, "Le juif Ngai, informateur du P. Mathieu Ricci," T'oung Pao 20, no. 1 (1920-1921): 32-39.

27 Ricci, China in the Sixteenth Century, 107-8.

28 Adolf Neubauer, “Jews in China,” Jewish Quarterly Review 8 (1895): 123-39. 
does not really seem acquainted with the religion of his fathers. Moreover, why would they conserve Hebrew texts if nobody could read them?

Another cliché is the typical Christian topic of the Messiah:

Ricci then sent the same brother on a second visit, this time to the ruler of the synagogue, with a letter, informing him that he had all the books of the Old Testament at his house in Pekin, together with a copy of the New Testament, containing the life and works of the Messiah, who he asserted had already appeared. The Archisynagogus took exception to this last remark and replied that the Messiah would not come for another ten thousand years.

I think that the synagogue speaker committed an error in speaking of ten thousand years before the coming of the Messiah. Perhaps this is an error on Ricci and Trigault's part, because according to Jewish belief, the age of the world amounts to 6,000 years.

This is similar to the fantastic story that Ricci was conferred the dignity of high priest (which cannot be attained!):

He added, however, that since they had heard so much of Ricci's reputation and learning, they would confer upon him the dignity of high priest of the Synagogue, if he would join their faith and abstain from eating pork.

The whole story ended-of course, I would say-with the Jews' conversion to Christianity:

Three other Jews came from that same city to Pekin later on, and as they were detained here for several days on business and were ready to receive the Christian faith, they decided to be baptized. One of these was a nephew of our first visitor, on the father's side. Our Fathers received them with hospitality and taught them a great deal about the Scriptures that was unknown to their Rabbis. When they learned that the Messiah had really come, they knelt down and prayed before his statue, as Christians do, and they were delighted with a compendium volume of the Christian faith, and with the other books on Christian doctrine, written in Chinese, which they brought back to their people. ${ }^{29}$

The reference to the Jewish scholars is a clear topos of Christian apologetics: the Jews do not know the most important parts of the Scriptures because they are hermeneutically and exegetically in the Christians' possession.

Ricci's strategy is to illustrate the "ignorance" of a few Jews in order to imply that of the Chinese Jews in general. This Latin argumentation of $a b$ uno disce omnes (Virgil, Aeneid 2:65-66)-which means that the whole may be inferred from one instance-is a sophism based on the pseudo-logical and pseudo-scientific inference according to which an attribute of a single object/substance may be ascribed to the whole. I do not have to explain how this well-known "principle" could be dangerous to human society.

29 Ricci, China in the Sixteenth Century, 108-9. 


\section{Christians}

For Ricci, Christianity also does not merit a long presentation, although there were many Christians families in the Northern provinces, ${ }^{30}$ who flourished in terms of number, education, and military strength (e fiorivano tanto in numero di famiglie, lettere et armi). Yet it is for this very reason that according to Ricci, they were suspected of rebellion, "perhaps accused by the Muslims who are in every part our enemies." This provoked mass conversions to Islam (whose converts are here called Turks), Judaism, or even atheism (whose converts are here called Gentiles), and their churches become temples for idolatry. Ricci states that their heirs have preserved the tradition of making the sign of the cross over food and drink, but they are also afraid of being considered their descendants and are ignorant of what this cross means. In contrast, the corresponding passage in Trigault is much longer, but he does not offer any novel information, speculating more on the word "cross" and its meaning for the Chinese. ${ }^{31}$

\section{Names of the "Sects"}

Near the end of the report, an important element is recorded by both Ricci and Trigault: the names of the "sects" according to Chinese custom. Ricci wrote:

All these foreigners [i.e., Muslims, Jews, and Christian] are called hoeihoei [回回] by the Chinese, a name whose origin we cannot ascertain. ${ }^{32}$ They call the Muslims ["macomettani"] hoeihoei of the three laws, they call the Jews hoeihoei who cut the nerves of the meat which they eat, the Chris-

30 See Hui Li, "Jesuit Missionaries and the Transmission of Christianity and European Knowledge in China," Emory Endeavors in World History 4 (2012): 48-63, downloaded from http://history.emory. edu/home/undergraduate/endeavors-journal/volume-4.html.

31 "Now to offer some evidence of the traces of Christianity, which we do very willingly, believing it should be of special interest to our friends in Europe. [...] There was no special word in their language to express the idea, and so our Fathers had to give them a Chinese word for it. In doing so they chose the Chinese character expressing the number ten, which is written in the form of a cross, thus + . It probably was not without the guidance of divine providence that a Christian in our day, selecting a name for the cross for the Chinese, should hit upon the very word that their ancestors had invented because of a similar paucity of symbolic expressions. In each instance the word selected was Scie-cu, meaning, the tenth. In so doing they really were not far afield from the practice observed in sacred literature, in which the cross is expressed by the letter T, which is even a more exact form than the one in question. When the conversation came around to designating the cross by this particular symbol, our friend the Israelite remembered that in Chaifamfu, the capital of his district, and in Lincin, a trading post in the Province of Sciantum, there were certain strangers whose ancestors came from abroad and who observed the religious custom of venerating a cross. They were accustomed, he said, to make a gesture with the hand in the form of a cross over their food and drink. He had no realization of the significance of such a rite and assured us that neither had the people in question who were accustomed to use it."

32 See Victor Escroignard, "Les Sarrasins des trois normes ou San Jiiao huihui," Acta Orientalia Academiae Scientiarum Hungaricae 45 (1991): 253-70. 
tians are called hoeihoei of the number ten because the letter of ten in China is a perfect cross and here there is no name that either uses for the word "cross." ${ }^{33}$ Beyond the name isai, which means iesuini, the Muslims ["maomettani"] call those Christians terzai. I heard from an Armenian that in Persia they call Armenians by this name. It may be that the Christians originally came from Armenia.

Trigault's “translation" is accordingly a correction and an addition of further details:

The three sects first discussed, called barbarian sects by the Chinese, are all designated by one common term, and their followers are all known as Hoei-hoei. What the origin of that name may be is still a puzzle to us. The more learned Chinese generally distinguish them as follows:

The Saracens are called Hoei because they abstain from pork.

The Jews are Hoei also because they do not eat the portion of meat containing the thigh nerve. This custom was introduced by the Jews because Jacob was stricken in that nerve.

Those who venerate the cross are called Hoei because they do not eat of the flesh of animals with rounded hoofs.

Although the Chinese and the Saracens and the Jews all partake of the flesh of horses, asses, and mules, this last class probably refrain from such meats in accordance with a custom peculiar to their race. The Chinese have other names also for this third class.

In general, they use the word Hoei with reference to those who follow the cult of the cross, while both Chinese and Jews say Hoei, referring to the Saracens. By this they mean that the Saracens belong to all three sects since they have adopted something of their belief from gentiles, Jews, and Christians. Besides the ordinary term Isai or Jesuini which the Saracens apply to all Christians, here in China the followers of the ancient cult of the cross are known to them as Terzai. The origin of this term is also uncertain, except that we have learned from a certain Armenian that in Persia the Armenians call the Christians by that same name. It might be concluded from this, with some probability, that the devotees of the cross had their origin in Armenia, and at various times found their way into China from the West. This could have happened when the vast armies of the Tartars poured over China, about the time, as it would seem, when the Venetian Marco Polo found his way hither. ${ }^{34}$

My surprise in reading this rendition of Trigault is his complete rewording of the text, which resolves some problems and complicates others. There are no "barbarian sects" (tres Barbarorum sectas, ut Sinae appellant) in Ricci, and the Muslims are called "Mohammedans" and not "Saracens." "Saracen" was a medieval term which had been used since the twelfth century, while "Mohammedan" was more recent, a product of the sixteenth century. ${ }^{35}$ Ricci defines the Muslims according to the three laws, which, as can be seen from another text (Nr. 725), were reported by a Jew called Nghaettien in 1605: "law" means "religion" and refers to Judaism, Nestorian Christianity, and atheism, i.e., Buddhism. Trigault defines Muslims by their food customs: they do not eat pork.

33 Fonti Ricciane, Nr. 174.

34 Ricci, China in the Sixteenth Century, 112

35 See David Thomas and John A. Chesworth, eds., Christian-Muslim Relations. A Bibliographical History. Volume 11: South and East Asia, Africa and the Americas (1600-1700) (Leiden: Brill, 2016), 434. 
Ricci defines the Jews as those who "cut the nerves of the meat which they eat." This is obviously erroneous, because the Jewish kashrut did not and does not address or include every nerve, but, according to the biblical book of Genesis, pertains only to the sciatic nerve: "Therefore the Children of Israel are not to eat the sciatic nerve to this day, because he struck Jacob's leg on the sciatic nerve" (32:33). Perhaps Ricci's aim was to find a difference between Muslims and Jews in the eyes of the Chinese because neither of them eat pork.

The complication is much more intriguing because those who venerate the cross, i.e., the Christians, are also defined by Trigault in reference to food customs: "Those who venerate the cross are called Hoei because they do not eat of the flesh of animals with rounded hoofs." This is a blatant error, because the Jews did not eat animals with rounded hoofs "according to their customs," which are prohibited as food in Jewish law (Leviticus 11), and they decisively do not venerate the cross.

The names of the sects testify only that the commonalities between the sects are based on food customs, as well as the differences. In other words: nobody knows what the difference is.

\section{Conclusion: Consciousness of Commonalities}

In 1940, the Archivum Historicum Societatis Iesu ${ }^{36}$ published a somewhat trenchant article by Edmond Lamalle attacking Nicolas Trigault. The author clearly defines Trigault's work as "propaganda" for his agency in favour of the mission in China. As I suggested at the beginning of this paper, Trigault did indeed produce his reworked translation of Ricci's work as pure propaganda for his missionary project. The book is not a report to narrate what Matteo Ricci did, but a reworked propagandic account intended to obtain money for the mission. Ricci's notes and experiences, hence, were instrumentalised to this goal. I do not intend to go beyond my task as a historian of ideas, but it is strange to describe the presence of Muslims, Jews, and "other" Christians based only on their differences in food customs.

I cannot understand why Ricci and Trigault devoted so few lines to the Muslims, a majority among the minorities, while Trigault mainly focused on presenting the Jews in an unequivocally negative light. There is an obvious negative vein in Ricci's original Italian work on the Muslims, which he defended with an indirect historical reference to the Turkish attacks on Christians, hence the sentence "the Muslims are in every part our enemies." ${ }^{37}$ Yet Ricci offered a very short report on all of them and did not negatively privilege the Jews in the context of the three "sects."

36 Edmond Lamalle, "La propagande du P. Nicolas Trigault en faveur des missions de Chine (1618)," Archivium Historicum Societatis Iesu 9 (1940): 49-120.

37 Nr. 171. 
It is important to underline that the use of strategic scepticism is always intended to demolish facts and logical discourse in order to establish new dogmatism and imperial power. Ricci's real aim is, of course, to keep his account about his meetings with religious groups in China, if any, very brief, because they are not the core of the book and are not representative of the Chinese Weltanschauung in this period. Trigault's real aim is to discredit all three religions or sects, the remnants of which-particularly in the case of the Jews-are incapable of understanding their own religion and writings. This gives a basis for asking European supporters to give money for a further a Jesuit mission to China. The Jesuit missionary show must go on.

\section{Bibliography}

d'Elia, Pasquale M., ed. Fonti Ricciane: documenti originali concernenti Matteo Ricci e la storia delle prime relazioni tra l'Europa e la Cina (1579-1615). 3 vols. Rome: La Libreria dello Stato, 1942-1949.

Deutsch, Yaacov. Judaism in Christian Eyes: Ethnographic Descriptions of Jews and Judaism in Early Modern Europe. Oxford: Oxford University Press, 2012.

Duigman, Peter. "Early Jesuit Missionaries: A Suggestion for Further Study." American Anthropologist 60 (1958): 725-32.

Escroignard, Victor. "Les Sarrasins des trois normes ou San Jiao Huihui." Acta Orientalia Academiae Scientiarum Hungaricae 45 (1991): 253-70.

Friedrich, Markus. Die Jesuiten. Aufstieg, Niedergang, Neubeginn. Munich: Piper, 2016.

Kublin, Hyman, ed. Studies of the Chinese Jews: Selected Articles from Journals East and West. New York: Paragon, 1971.

Lamalle, Edmond. "La propagande du P. Nicolas Trigault en faveur des missions de Chine (1616)." Archivium Historicum Societatis lesu 9 (1940): 49-120.

Laytner, Anson H., and Jordan Paper, eds. The Chinese Jews of Kaifeng: A Millennium of Adaptation and Endurance. Lanham, MD: Lexington Books, 2017.

Li, Hui. "Jesuit Missionaries and the Transmission of Christianity and European Knowledge in China." Emory Endeavors in World History 4 (2012): 48-63.

Neubauer, Adolf. "Jews in China." Jewish Quarterly Review 8 (1895): 123-39.

Pelliot, Paul. "Le juif Ngai, informateur du P. Mathieu Ricci.” T’oung Pao 20, no. 1 (1920-1921): 32-39.

Purchas, Samuel. Hakluytus Posthumus in fiue books [...] London, 1625.

Ricci, Matteo [Matthew]. China in the Sixteenth Century: The Journals of Matthew Ricci, 1583-1610. Translated by Louis J. Gallagher. New York: Random House, 1953.

Ricci, Matteo. Opere storiche del padre Matteo Ricci. Edited by Pietro Tacchi. 2 vols. Macerata: F. Giorgetti, 1911-13.

Ruggieri, Michele, and Matteo Ricci. Dicionário Português-Chinês: 葡漢辭典 (Pu-Han cidian): Portuguese-Chinese Dictionary. Edited by John W. Witek. Lisbon and San Francisco: Biblioteca Nacional Portugal, Instituto Português do Oriente and Ricci Institute for ChineseWestern Cultural History, University of San Francisco, 2001.

Thomas, David, and John A. Chesworth, eds. Christian-Muslim Relations. A Bibliographical History. Volume 11: South and East Asia, Africa and the Americas (1600-1700). Leiden: Brill, 2016.

Trigault, Nicholas. De Christiana expeditione apud Sinas suscepta ab Societate Jesu. Ex P. Matthaei Riccij eiusdem societatis commentarijs, libri V: Ad S.D.N. Paulum V. In quibus 
sinensis regni mores, leges, atque instituta, \& novae illius Ecclesiae difficillima primordia accurate \& summa fide describuntur. Leiden, 1616.

Veltri, Giuseppe. Alienated Wisdom: Enquiry into Jewish Philosophy and Scepticism. Berlin and Boston: De Gruyter, 2018.

Veltri, Giuseppe. "The Principle of Coscientia: The Averroist Joshua ha-Lorki.” Forthcoming. 